\title{
A SURVEY ON CRITICAL LITERACY AS A PEDAGOGICAL APPROACH TO TEACHING ENGLISH IN INDONESIA
}

\author{
Gin Gin Gustine \\ Universitas Pendidikan Indonesia, Indonesia \\ gustine@upi.edu
}

First received: 27 July 2017

Final proof received: 31 January 2018

\begin{abstract}
In English-as-a-Foreign-Language (EFL) context, critical literacy as an alternative approach to teaching language and literature may be considered as something new, compared to its origin in some English-speaking countries such as Australia or the USA. Teachers wishing to adopt critical literacy stance in their class are often left with little knowledge or experience on what critical literacy is and how to develop this approach in their class. This article discusses the result of a survey involving twenty one English teachers in a teacher education university in Bandung, West Java province, Indonesia, related to their knowledge on critical literacy as an approach to teaching English language. Result of questionnaires followed up by a focus group discussion reveals that although these teachers have been teaching English for approximately five to seven years in different levels of schools, some teachers show lack of knowledge on critical literacy as a methodological approach to teaching English. Finally, this article concludes with suggestions for English teachers to develop a critical literacy-oriented classroom.
\end{abstract}

Keywords: critical literacy; English as a Foreign Language (EFL); EFL methodology

In the EFL Methodology class that I taught to graduate students in September 2015, most of whom are in-service English teachers, I asked the students to write an essay about the characteristics of 'good' English teachers in the $21^{\text {st }}$ century. Reading through the students' essays, I stumbled upon the frequency of words such as "critical teachers" and "critical thinking" appearing in their essay as they referred to some traits of good English teachers. In a classroom discussion that followed, I tried to verify some concepts frequently appearing on the students' essays. Much to my surprise, these students, some of them have been teaching English for five to seven years, still have a vague idea on what they meant by critical teachers, critical thinking or how to create critical English classrooms. Furthermore, their idea on how to assist students to become critical learners was not very clear, although some strategies such as providing opportunities for students to ask questions were explicitly mentioned.

Apart from the concepts of critical teachers and critical thinking that seemed to create a puzzle to some students, when I introduced the words 'critical literacy', this seemed to only add more confusion, as some of the students admitted that they had never heard of this before. Meanwhile for the rest of students, critical literacy is the same as critical thinking as both of the concepts encourage students to think critically towards an issue. Some other students believed that critical literacy requires higher order thinking as often found in critical thinking.

The above fact illustrates that, despite the ongoing importance of critical literacy in education, some teachers, even those who have been teaching English for more than five years, are still unsure about what critical literacy means for them as the teachers and what strategies they can offer to their students in order to help students develop their critical mind.

This article aims to explore the meaning of critical literacy for in-service English teachers as well as strategies to help students develop their critical literacy capacity and what English teachers know about critical literacy as a pedagogical model, and thus the paper will meet these aims in the following ways. First, a brief history and development of critical literacy, especially in English language teaching, will be illuminated as a major theory underpinning the study. Second, an overview of the method in this study will be illustrated followed by finding and discussion section. Finally, this article ends with suggestions for English teachers to develop critical literacyoriented classroom.

A brief history of critical literacy and its development in English language teaching Rooted in the Greek language, the word 'critical' (kritikos) literally means to be able to argue and judge, while literacy means reading and writing. Combined together, critical literacy means the ability to argue and judge what is read and what is written. However, critical literacy has experienced a major change in its meaning, especially in terms of reading and writing.

The notion of critical literacy cannot be separated from a powerful work by Freire (1970) 
through his book Pedagogy of the Oppressed. Freire believes that being literate (reading the word) will enable people to be fully aware of the social and political situation where they live (reading the world). Following Freire, critical education theorists such as Janks (2014), for example, continue to raise educators' awareness on the ongoing importance of critical literacy in education, as she powerfully described in the following statement.

In the actual world — where a 17- year- old boy sells one of his kidneys for an iPad; where adult men rape babies; where rebel fighters video themselves mutilating and cannibalizing the body of an enemy soldier to post on YouTube; where imprisonment without trial and torture are condoned; where children are molested by adults they trust; where millions of people lack access to drinking water or sanitation; the list is endless-it is even more important that education enables young people to read both the word and the world critically (Janks, 2014, p. 249).

Janks' statement demonstrates that critical literacy should be explicitly immersed and taught in today's education, as it empowers students to be able to connect what they read and see with the reality of the world they are living in. This is actually the heart of critical literacy education. It does not separate or exclude students' experience with the world; in fact, critically-literate students often understand reality from different perspectives.

The ability to investigate an issue from multiple points of views, as in line with the spirit of critical literacy elaborated in Jank's (2014) statement above, is also highly relevant to current Indonesian social and political situation which tends to create a spark in communal tension. Information related to political leaders and their movement published daily in Indonesia is often perceived as the truth by some people without any further investigation, or any need to compare "the truth" from different perspectives. This demonstrates that critical literacy continuously gains its importance in almost every aspect of our life, not only in social and political dimensions, but also in education.

In English language teaching, critical literacy is interpreted in many different ways in teaching and learning sphere despite the fact that some experts reject the idea that critical literacy is merely about methodology (McLaughlin \& DeVoogd, 2004). Some proponents of critical literacy education believe that, at the end, critical literacy should be considered as a way of thinking and furthermore, a way of life (McDaniel, 2006). In its development, English teachers implementing critical literacy in their classes often start with nurturing a habit of asking questions which includes investigating what is perceived as normal in everyday life. For example, teachers may wish to start asking students to identify how a certain text positions people and how people are constructed; whose voice is missing from the text and whose voice is heard; which gender is viewed as more important in the text; how language is used to maintain domination, and so on (Van Sluys, 2005).

However, despite the importance of critical literacy in education as stated above, many teachers, especially in some Asian countries where English is often used as a foreign language, are still lacking of knowledge on its implementation in the class (Falkenstein, 2003; Kim, 2012; Ko, 2010). Apart from teachers' insufficient knowledge of how critical literacy should be put into practice, in EFL context, some challenges that critical literacy educators face in the classroom have been identified as well. For example, challenges related to cultural appropriateness (Kuo, 2009; Hu, 2002); the existing banking pedagogy in EFL classrooms (Ko, 2010); deficit assumption from foreign educators on the ability of EFL students to take critical viewpoint (Falkenstein, 2003); and finally, a stereotypical perspective that views Asian students as submissive and dependent learners (Shin \& Crookes, 2005).

This research aims to reveal English teachers' knowledge on what critical literacy is and what it means as a pedagogical approach as well as their strategies to construct critical English classrooms in Indonesian context. This area of critical literacy, especially in Indonesian EFL setting, has not been well-researched, and thus this research aims to deepen limited research on critical literacy research in EFL context (Ko \& Wang, 2009).

\section{METHODS}

In order to investigate the teacher's knowledge of critical literacy as a pedagogical approach to teaching English, I conducted a small scale online survey followed by a focus group discussion. There are three research questions underpinning the study: (1) what does critical literacy mean for English teachers?; (2) how do English teachers perceive critical literacy as a pedagogical approach?; (3) what are the teachers' effort to develop a critical literacyoriented English classrooms?. To answer these questions, the survey was in the form of open-ended questionnaire and distributed to a class consisting of twenty one master-degree students majoring in English education, most of whom have been teaching at different school levels between two to seven years. At the time the research was conducted, all of the participants were post-graduate students (whose names were in pseudonym) enrolled in the EFL Methodology class that I taught in September 2015.

In line with the three research questions, the questionnaires were developed in accordance with the research aims. Before I distributed the questionnaires, they were then reviewed by some colleagues who did not participate in the study to 
ensure the clarity of each of the items asked (Patten, 2017). The questionnaires were all open-ended and consisted of three main parts. The first section was related to the participants' knowledge of critical literacy in general, including its differences from critical thinking. The second theme was the participants' perspectives of the critical literacy as a pedagogical model in English teaching and learning. And the third was the teachers' efforts to develop critical literacy in their English class.

Apart from the questionnaire, I also conducted a focus group discussion in which I invited all participants to engage in a topic related to the themes in the questionnaire. To ensure the quality of the focus group discussion, the questions in the session were predetermined and sequenced so they were clear and logical to participants (Krueger \& Casey, 2015). The questions were all related to the participants' responses to the questionnaires. Out of twenty one respondents, only nine volunteered for the focus group discussion that lasted for about 90 minutes and was conducted a week after they filled out the questionnaires. During the discussion, I acted as a moderator who prepared and asked questions to the participants in an effort to create a natural discussion which ran smoothly while maintaining the essence of the discussion. The discussion was recorded and transcribed immediately.

Using inductive content analysis (Zhang \& Wildemuth, 2009), data from both the questionnaires and the focus group discussion were analysed to find emerging themes related to the teachers' knowledge on critical literacy, and what it means as a pedagogical model in English teaching and what strategies teachers need to develop a critical literacy-oriented English classroom.

\section{FINDINGS AND DISCUSSIONS}

The following section discusses the findings and discussions from the questionnaires and the focus group discussion. The findings and discussions are divided into three main issues in accordance with the research questions. The first theme examines the respondents' perception of critical literacy; the second sub-section explores the critical literacy as a pedagogical model of teaching English; while the last theme investigates the teachers' efforts to develop critical literacy in English classroom.

\section{What critical literacy means for in-service English teachers}

The first theme in the questionnaire was related to participants' understanding of critical literacy from their perspectives and experience as English teachers. Responding to this question, almost all respondents confused critical literacy with critical thinking. For example, from the perspectives of English teachers, one respondent, Adia, mentioned that critical literacy meant encouraging students to read critically and be able to differentiate facts from opinions. Some other participants believed that in critical literacy, students are required to examine the content and validity of the source and be critical with any information they received.

Some of the characteristics of critical literacy that respondents stated above, such as the ability to read critically, the ability to differentiate facts from opinions, and the ability to critically investigate the validity of information they receive, are actually highly relevant to critical thinking. Some proponents of critical thinking such as Ennis (2015) suggested that in doing critical thinking students are engaged with those skills mentioned before. However, in critical literacy education, the goal is one step ahead. Students and educators engaged in critical literacy should begin to think from wider and more critical perspectives; for example, when students read something, they should be able to question whose voice is heard in this particular text and whose voice is not heard, why this text is written this way and who benefits, how is this text trying to position me, etc. (Harste et al., 2000; Lewison, Leland, \& Harste, 2015; Luke \& Freebody, 1999; Van Sluys, 2005).

Apart from the teachers' misunderstanding between critical literacy and critical thinking, another response related to this question was the way the teachers associated critical literacy solely with reading. As an illustration, only four out of twenty-one participants linked critical literacy both with reading and writing. Another respondent, Rio, stated that to engage in critical literacy, one had to be able to put their critical thinking into writing. In line with this point of view, another participant agreed that critical literacy entailed people to write with their prior knowledge and experience and thus their writing reflected a reality. As opposed to these responses that related critical literacy with writing, most of the teachers participated in this study believed that critical literacy engaged students in reading with critical mind. From this finding, it may be inferred that to some teachers, literacy is still defined narrowly to reading and writing skills only as evident in the way participants linked critical literacy with the above skills. Meanwhile, "literacy", in critical literacy education, has undergone a significant change from the ability to read and write, which often relates to technical communication skills (Kalantzis \& Cope, 2012), to a process of learning in which we learn how to make meaning to change the world (Freire \& Macedo, 1987). In the recent trend, the ability to make meanings embedded in critical literacy is facilitated by the use of texts from various spheres such as the internet, videogames, visual images, graphics, and layout (Gee, 2003).

The first theme in the questionnaire has discussed teachers' perspectives on what critical 
literacy means for them as English teachers. The following subsection elaborates critical literacy as a pedagogical model in English teaching.

\section{Critical literacy as a pedagogical model in English teaching}

Unlike in the first question in which almost all of the respondents had vague ideas of what critical literacy is, in the second question almost all of the respondents believed that critical literacy may be implemented as one of the alternative models in English teaching. However, a question remained as to how critical literacy is manifested in EFL class.

Some respondents believe that as a pedagogical model in EFL, critical literacy plays a positive role in helping students to read beyond the text. However, when teachers focused on implementing critical literacy in the class, one of the participants was afraid that the classroom atmosphere would be dull and uninteresting as described by Nadine, a participant who had been teaching for about four years. She explained that critical literacy may be useful when teachers wanted to design a class that focused more on "text". Nadine further said:

I think we can design our English class with some principles of critical literacy pedagogy. For example, we asked students about the main idea of certain paragraphs, then we asked what it meant, and so on and so forth. However, I think when teachers focused too much on critical literacy, the class will become boring because we spent too much time on text, on discourse. I'm afraid students will not be interested because of that.

Nadine's explanation about critical literacy has included two perspectives. First, she related critical literacy with how to understand the meaning beyond the text. This point of view is in line with some proponents of critical literacy pedagogy who argue that critical literacy is related to examining the underlying ideology of the writer or the author's purposes (Cervetti, Pardales, \& Damico, 2001; Luke, 2012). In other words, as a pedagogical model, critical literacy should enable students to challenge that no text is neutral (McNicol, 2016) and that it is always about someone's truth or reality.

Nadine's second account of critical literacy, however, may have raised an alarm that critical literacy is a difficult subject, as it closely related to examining the meaning beyond the text. To some extent, this kind of pedagogical model to teaching English may pose certain challenges, especially for teachers who are unfamiliar with critical literacy (Gustine, 2014) and thus may have interpreted critical literacy in a different perspective. Without doubt, critical literacy requires learners to engage with texts critically, and to be able to do that, a detailed examination to texts is needed. In other words, learners are required to crack the "code" such as being able to identify the features and structures of the texts; for example, the patterns and convention of sentence, grammar, spelling and many more (Luke \& Freebody, 1999). Nadine was anxious if this kind of activity embedded in critical literacy may have distracted students' - as well as teachers'-expectation in learning English. Therefore, she believed that the classroom situation will be uninteresting.

To some teachers who have been engaged with critical literacy, there are some strategies that may be used to trigger students' interests in learning English. For example, critical literacy may be used along with popular culture and use everyday texts that are close to students' life (Comber \& Nixon, 2005; Evans, 2005; Fisher, 2005; Millard, 2005; Vasquez, 2005).

The second subsection here has elaborated mainly on Nadine's account about what she believes related to critical literacy as a pedagogical approach. The final findings subsection below discusses the teachers' efforts to create a critical literacy-oriented English classroom.

\section{The teachers' efforts to develop critical literacy-} oriented English classroom

The last theme of the questionnaire was to investigate the participants' efforts to develop critical literacy-oriented English class. When it comes to some practical suggestions, teachers seemed to be unsure about how and where to start. Apart from that, students' English language proficiency seemed to become a major concern for the participants in this study. Related to English language proficiency, the responses were divided into two: those who believed that it can only be taught to students with advanced English proficiency level and those who assumed that critical literacy can be taught to all students regardless their English proficiency level.

Although some participants have elicited their knowledge on critical literacy and its pedagogical model in English teaching as presented in the previous result, when it comes to what should be done in order to develop a critical literacy-oriented English classroom, the participants showed some signs of uncertainty. One respondent, Lea, believed that teachers' education background played an important role in helping the teachers' capability to design and develop a critical English classroom. She argued that in order to develop a critical literacyoriented English classroom, teachers must have graduated, at least, from Master degree in English education. She related her experience when she attended undergraduate study in which the program did not provide any training related to developing critical English classroom. At the discussion, other participants, Ray, Sita and Adit, agreed to Lea's opinion. They believed that through higher 
education, teachers may gain advanced knowledge, skills as well as confidence to develop their English classroom to be more critical.

Apart from teachers' formal education that some respondents mentioned, some participants agreed that teachers should have engaged in short courses or professional development to help them improve their professionalism related to English teaching and learning in general, and specifically to critical literacy. Ali, a respondent who taught at a remote island in far east of Indonesia emphasized that a professional development in critical literacy for English teachers is a must, especially for teachers in isolated area who often have restricted access to professional development compared to teachers in big cities.

On the other hand, some other participants who seemed to grasp basic knowledge and understanding of critical literacy in English teaching and learning tended to have a strategic plan to develop a critical English classroom. Inda, a teacher from central Java who has been teaching for about six years, mentioned some strategies to develop a critical literacy-oriented classroom such as teachers' ability and willingness to listen to students' opinions rather than discouraging students to express their opinions in the class. Inda further said that, "I know some teachers sometimes are not comfortable when students express their opinions. But on the other hand, there are also some other teachers who have no idea how to help students to be expressive in their opinions. I think if you want to have a critical English classroom, you have to encourage students to talk". When I asked the group why this particular strategy may work in a critically literate English classroom, Inda further said that sometimes it is important to listen to your students' opinions. She related this with her experience when she taught English in a high school:

Once I had a student who was very quiet, he could spend almost the entire day without participating in the class. When I tried to approach him, I asked a lot of questions that were intended for him only. Then suddenly he talked, he talked a lot. All his friends were very surprised and he seemed to enjoy himself talking in the class where everyone was listening.

Note how Inda chose the word "very quiet", and "spend almost the entire day without participating" which could have been misinterpreted as a disengaged student by some other teachers. Instead, rather than focusing more on the student's lack of participation, Inda shifted the focus on her as the teacher who believed that the student may have a hidden potential. Inda deliberately changed her strategy to invite him to participate in the class by "asking a lot of questions that were intended for him only", which proved to be an effective strategy as now the student seemed to gain confidence to participate in the class.
Inda may have not realized that what she did as the teacher is very significant to the development of a critical English classroom. In the perspective of critical literacy education, encouraging students whose voice is not heard may suggest the teacher's effort to create social justice in the class which is central to critical literacy (Lewisonet al., 2015).

Another strategy to develop a critical English classroom was the teachers' ability to modify the textbook used. Ali said if teachers continued to use only the textbook in the classroom, he doubted that students will be exposed to thinking critically which is essential in critical literacy education. Moreover, Ali added that textbook tends to address issues that are not always relevant to the current situation. As an illustration, he mentioned that he has been using textbooks merely to help students develop language skills. Ali believed that it will be difficult for teachers to fully rely on textbook if teachers wanted to develop a critical English classroom.

Ali's opinion was also supported by some other teachers during group discussion. For example, Sita asked if it is acceptable to use textbook to nurture critical literacy in the class. Some teachers agreed with Ali that it is rather impossible for teachers to develop critical literacy in the class through textbooks. Ali's and some other teachers' point of view may have indicated teachers' lack of knowledge on the relationship between critical literacy and the everyday world.

These three subsections have elaborated major findings as well as analysis from the study. The last section below is the conclusion and suggestions for English teachers who wish to include critical literacy in their class.

\section{CONCLUSION AND SUGGESTION}

From the result of questionnaires and focus group discussion, it may be inferred that despite the teachers' lack of knowledge of critical literacy in EFL education, this research brings hope that English teachers embrace the notion of critical literacy and its pedagogical practice into their classroom. Although most teachers in this study may not fully grasp the essence of critical literacy in English teaching, some of the respondents have raised a critical awareness of what critical literacy looks like in the classroom, and how to create a critical literacy-oriented English classroom.

For educators who yearn to adopt critical literacy, some experts in this field have elaborated strategies which may be used in EFL class. First, critical literacy starts with everyday texts (Lewison et al., 2015; Van Sluys, 2005; Vasquez, 2005) in which teachers lead students to problematize what is perceived as normal in the society. Therefore, teachers may also start with the textbook used at school and start to question how people are presented in the textbook (Van Sluys, 2005), and 
challenge students to identify whose voice is heard and whose is missing (Luke, 2012). Apart from the everyday texts that have their own importance in critical literacy education, teachers may also want to include popular culture embedded in critical literacy. Research demonstrates that picture books (Exley, 2013), graphic novels (Maloy, 2016), songs (Lloyd, 2003), even toys such as Barbie dolls (Stone, 2017) are some of the popular culture that have gained their popularity among literacy teachers across the globe.

With the limitation on critical literacy research in EFL setting, this study may cast light on English teachers in Indonesia related to critical literacy and its implementation. Therefore, for further research, a longer study involving more teachers across regions in Indonesia would be beneficial. With more time, it is expected that we would be able to investigate the matter deeper as well as document changes and challenges they may experience in their classes.

Finally, building on this research, I would like to encourage literacy educators to introduce critical literacy to pre-service English teachers. With the current social and political tensions in Indonesia, students need to be equipped with critical literacy mindset. However, without critically literate teachers, this objective may not be fully accomplished. An effective professional learning on critical literacy with an emphasis on working collaboratively with teachers may be one of the ways to achieve the goal. The literacy movement (Gerakan Membaca) currently launched by the Indonesian education ministry may be a seed to basic literacy that we need to nurture, in the hope that it will help to create a critically literate Indonesian generation in the future.

\section{REFERENCES}

Cervetti, G., Pardales, M. J., \& Damico, J. S. (2001). A tale of differences: Comparing the traditions, perspectives, and educational goals of critical reading and critical literacy. Online, 4(9).

Comber, B., \& Nixon, H. (2005). Children reread and rewrite their local neighborhoods: Critical literacies and identity work. In J. Evans (ed). Literacy moves on: Popular culture, new technologies, and critical literacy in the elementary school (pp. 127-148). Portsmouth: Heinemann.

Ennis, R. H. (2015). Critical thinking: A streamlined conception. In Davies, Martin, \& Ronald Barnett (eds.), A handbook of critical thinking in higher education (pp. 31-47). New York: Palgrave Macmillan.

Evans, J. (2005). Beani babies: An opportunity to promote literacy development or a moneyspinner for the business tycoons?. In J. Evans (ed). Literacy moves on: Popular culture, new technologies, and critical literacy in the elementary school (pp. 106-126). Portsmouth: Heinemann.

Exley, B. (2013). Using children's picture books to develop students' critical literacy responses. In Promoting Creativity in Primary English Education, The Korean Association of Primary English Education (KAPEE) (pp. 1-8). Seoul National University of Teacher Education, South Korea.

Falkenstein, A. (2003). Critical literacy in an EFL context (Unpublished doctoral dissertation). Indiana University, United States.

Fisher, R. (2005). Curiosity kits: Linking reading and play in the middle years. In J. Evans (ed). Literacy moves on: Popular culture, new technologies, and critical literacy in the elementary school (pp. 149-160). Portsmouth: Heinemann.

Freire, P. (1970). Pedagogy of the oppressed (M.B. Ramos, Trans.). London: Penguin Books.

Freire, P., \& Macedo, D. P. (1987). Literacy: Reading the word and the world. South Hadley, Mass.: Bergin and Garvey.

Gee, J. (2003). What video games have to teach us about learning and literacy. New York: Palgrave Macmillan.

Gustine, G. (2014). Critical literacy in an Indonesian context: Sustaining professional learning (Doctoral Thesis). Geelong: Deakin University, Australia. http://dro.deakin.edu.au/eserv/DU:30067332/g ustine-critical-2014.pdf

Harste, J., Vasquez, V., Lewison, M., Beau, A., Leland, C., \& Ociepka, A. 2000. Supporting critical conversation in classrooms: A review of more than 50 picture books and young adult novels', in Kathryn Mitchell Pierce (ed.), Adventuring with books (4th ed.). Urbana: NCTE Urbana.

Hu, G. (2002). Potential cultural resistance to pedagogical imports: The case of communicative language teaching in China. Language, Culture and Curriculum, 15, 93105.

Janks, H. (2014). Critical literacy's ongoing importance for education. Journal of Adolescent and Adult Literacy, 57(5), 349356.

Kalantzis, M., \& Cope, B. (2012). Literacies. Cambridge: University of Cambridge Press.

Kim, S. J. (2012). Critical literacy in East Asian literacy classrooms. Perspectives on Global Development and Technology, 11(1), 131-144.

Ko, M.-Y. (2010). Critical literacy development in a college-level English reading class in Taiwan (Doctoral dissertation). Indiana University, Indiana.

Ko, M.-Y., \& Wang, T.-F. (2009). Introducing critical literacy to EFL teaching: Three Taiwan 
college teachers' conceptualization. Asian EFL Journal, 11(1), 174-191.

Krueger, R., \& Casey, M. (2014). Focus group: A practical guide for applied research. Singapore: SAGE Publications.

Kuo, J.-M. (2009). Critical literacy and a picturebook based dialogue activity in Taiwan. Asia Pacific Educational Review, 10, 483-494.

Lewison, M., Leland, C., \& Harste, J. C. (2015). Creating critical classrooms: $K-8$ reading and writing with an edge. New York: Lawrence Erlbaum.

Lloyd, C. (2003). Song lyrics as texts to develop critical literacy. Reading Online, 6(10), 22-35.

Luke, A \& Freebody, P. (1999). A map of possible practices: further notes on the four resources model. Practically Primary, 4(2), 5-8.

Luke, A. (2012). Critical literacy: Foundational notes. Theory into Practice, 51(1), 4-11.

Maloy, M. (2016). Graphic novels and critical literacy theory: Understanding the immigrant experience in American public schools. Education Doctoral, Paper 250.

McDaniel, C. (2006). Critical literacy: a way of thinking, a way of life. New York: Peter Lang Publishing.

McLaughlin, M., \& DeVoogd, G., L. (2004). Critical Literacy: Enhancing Students' Comprehension of Text. New York: Scholastic.

McNicol, S. (2016). Renegotiating the place of fiction in libraries in critical literacy. In S. $\mathrm{McNicol}$ (ed), Critical literacy for information professionals (pp. 3-18). London: Facet Publishing.
Millard, E. (2005). Writing heroes and villains: Fusing children's knowledge about popular fantasy texts with school-based literacy requirements. In J. Evans (ed). Literacy moves on: Popular culture, new technologies, and critical literacy in the elementary school (pp. 161-184). Portsmouth: Heinemann.

Patten, M. (2017). Questionnaire research: A practical guide. New York: Routledge.

Shin, H., \& Crookes, G. (2005). Exploring the possibilities for EFL critical pedagogy in Korea: A two-part case study. Critical Inquiry in Language Studies, 2, 113-130.

Stone, K. (2017). Reconsidering primary literacy: Enabling children to become critically literate. New York: Routledge.

Van Sluys, K. (2005). What if and why: Literacies invitations for multilingual classrooms. Portsmouth, NH: Heinemann.

Vasquez, V. (2005). Creating opportunities for critical literacy with young children: Using everyday issues and everyday texts. In J. Evans (ed). Literacy moves on: Popular culture, new technologies, and critical literacy in the elementary school (pp. 83-105). Portsmouth: Heinemann.

Zhang, Y., \& Wildemuth, B. M. (2009). Unstructured interviews. In B. Wildemuth (Ed.), Applications of social research methods to questions in information and library science (pp. 222-231). Westport, CT: Libraries Unlimited. 